\title{
Food resources influence levels of persistent organic pollutants and stable isotopes of carbon and nitrogen in tissues of Arctic foxes (Vulpes lagopus) from the Pribilof Islands, Alaska
}

\author{
Jennie L. Bolton ${ }^{a}$, Paula A. White ${ }^{b}$, Douglas G. Burrows ${ }^{a}$, Jessica I. Lundin ${ }^{a}$ \& Gina M. Ylitalo
}

${ }^{a}$ Environmental and Fisheries Sciences Division, Northwest Fisheries Science Center, Seattle, WA, USA; ${ }^{b}$ Museum of Vertebrate Zoology, University of California, Berkeley, Berkeley, CA, USA

\section{ABSTRACT}

The Arctic fox (Vulpes lagopus) is a small canid with a circumpolar Arctic distribution. Several subspecies are recognized, including a subspecies known as the Pribilof fox (V. I. pribilofensis) endemic to the Pribilof Islands of Alaska, USA. Pribilof fox tissues were collected from the islands of St. Paul $(n=38)$ and St. George $(n=13)$. Levels of persistent organic pollutants (POPs) and stable isotopes of carbon and nitrogen were measured and the findings related to sex, age class, island and access to anthropogenic food resources using ANOVA and principal component analysis. The rank order for POPs in fat was polychlorinated biphenyls ( $\Sigma$ PCBs) $>$ chlordanes $(\Sigma \mathrm{CHLs}) \gg$ hexachlorocyclohexanes $(\Sigma \mathrm{HCHs})>$ DDTs $(\Sigma \mathrm{DDTs})>$ hexachlorobenzene $(\mathrm{HCB}) \sim$ polybrominated diphenyl ethers ( $\left.\sum \mathrm{PBDEs}\right)$. Adult females had lower mean levels of most POPs ( $\Sigma$ PCBs, $\Sigma C H L s, \Sigma H C H s, \Sigma D D T s$ ) and lower $\delta^{15} \mathrm{~N}$ values than adult males. Foxes on St. Paul had significantly higher levels of most POPs than those on St. George, though St. George foxes were significantly higher in HCB. Foxes with high probability of access to anthropogenic foods had significantly lower levels of $\Sigma$ DDTs and lower $\delta^{15} \mathrm{~N}$ values than foxes with a low probability of access. The observed differences in contaminant and stable isotope levels were consistent with fox use patterns of different food resources. POP concentrations in the tissues of some Pribilof foxes, especially from St. Paul, were higher than those associated with thresholds for adverse health effects. POPs may therefore be a factor for consideration in the conservation of Pribilof foxes.

\section{KEYWORDS}

Bering Sea; marine food web; Pribilof fox conservation; feeding ecology; POPs

\section{ABBREVIATIONS}

ANOVA: analysis of variance; Cl: confidence interval; DDT: dichlorodiphenyltrichloroethane pesticide plus dichlorodiphenyldi-

chloroethane and dichlorodiphenyldichoroethylene; GC/MS: gas chromatography / mass spectrometry; GLM: general

linear model; $\mathrm{HCB}$ :

hexachlorobenzene; LOQ: lower limit of quantitation; NOAA: National Oceanic and Atmospheric Administration; NWFSC: Northwest Fisheries Science Center; PCA: principal component analysis; $\mathrm{PCB}$ polychlorinated biphenyl POP: persistent organic pollutant; SRM: standardized reference material; TLC/FID: thin-layer chromatography / flame ionization detection; Tukey's HSD: honest significant difference test.

\section{Introduction}

POPs, including PCBs and DDTs, are found in biota throughout the Arctic (reviewed by Letcher et al. 2010). These contaminants are transferred to the Arctic via atmospheric transport and ocean currents (Barrie et al. 1992; Iwata et al. 1993; de Wit et al. 2004) or via biotransport (Evenset et al. 2007; Lukyanova et al. 2014). Because these compounds are lipophilic and highly persistent (Muir \& Norstrom 2000; de Wit et al. 2004), they may cycle within the marine food web for decades. The highest concentrations of POPs measured in Arctic biota are found in marine mammals because they are relatively long-lived, their bodies often contain high amounts of lipid where lipophilic POPs can readily accumulate, and they often feed within relatively complex marine food webs (Norstrom \& Muir 1994; Norstrom et al. 1998; Beckmen et al. 1999; Muir \& Norstrom 2000; Kucklick et al. 2002; Krahn et al. 2006).

Levels of POPs in many species of marine mammals have been found to vary not only with diet, but also in accordance with different life history parameters such as age class and reproductive status. For example, reproductive females may have lower levels of POPs compared to males, or to juvenile or senescent females, because they transfer a significant share of their body burdens of contaminants to their offspring via gestation and lactation (Beckmen et al. 1999; Ylitalo et al. 2001; Debier et al. 2003). Consequently, juvenile animals may have higher levels of certain POPs than adults (Tuerk et al. 2005; Krahn et al. 2007; Ylitalo et al. 2009). In

CONTACT Jennie L. Bolton jennie.bolton@noaa.gov Environmental and Fisheries Sciences Division, Northwest Fisheries Science Center, National Marine Fisheries Service, National Oceanic and Atmospheric Administration, 2725 Montlake Boulevard East, Seattle, WA 98112, USA 
particular, first-born surviving offspring may receive the largest share of their mother's burden of contaminants and therefore accumulate higher levels of POPs than subsequent siblings (Ylitalo et al. 2001). Adult males may likewise accumulate high levels of POPs, reflective of their lifetime exposures.

Stable isotopes of carbon and nitrogen have been used to elucidate information about the relative trophic levels of animals (Kelly 2000; Fisk et al. 2003), to assess spatial and temporal differences in prey (Krahn et al. 2006; Ehrich et al. 2015) and to determine the relative contributions of different carbon sources (e.g., terrestrial vs. marine; nearshore vs. offshore) to diets (Hobson et al. 1994; Schell et al. 1998). Stable isotopes have also been used to describe the effects of trophic level on the biomagnification factors of POPs within marine food webs (Fisk et al. 2003). Stable isotope signatures of muscle reflect a dietary time frame over a period of months (Roth \& Hobson 2000) and therefore give a more comprehensive picture of an animal's dietary intake compared to methods that report on discrete feeding events such as observation of predation events or examination of stomach contents (Kelly 2000).

A subspecies of the Arctic fox (Vulpes lagopus) known as the Pribilof fox (V. l. pribilofensis) is endemic to the Pribilof Islands of Alaska. Pribilof foxes feed primarily on northern fur seal (Callorhinus ursinus) carcasses and placentas as well as on marine birds and their eggs (White 1992), all of which may contain high tissue levels of POPs (Beckmen et al. 1999; Loughlin et al. 2002; Vander Pol et al. 2004; Elliott 2005; Braune 2007). Food resources available to foxes vary in proportion between the Pribilof Islands of St. Paul and St. George, with St. Paul foxes relying more on fur seal rookeries and St. George foxes preying more heavily on seabirds (White 2001). There are also terrestrial food resources consisting of small herds of introduced caribou (Rangifer tarandus) present on each island, lemmings (Lemmus nigripes) that are native to St. George, and house mice (Mus musculus) that have been introduced into the town of St. Paul. Anthropogenic food resources such as table scraps (processed and store-bought foods) or pet food may be directly provided, and foxes also scavenge refuse in towns and at the city dumps. Additionally, humans at times provide foxes with remains of harvested seals, crab or fish (scraps, discarded bait and carcasses) in quantities far exceeding what foxes would normally encounter (White 2010).

Relatively few studies have been published on POP levels in Arctic foxes (Clausen et al. 1974; Norheim 1978; Wang-Andersen et al. 1993; Skaare 1996; Hoekstra et al. 2003; Fuglei et al. 2007; Andersen et al. 2015), and only that of Hoekstra et al. (2003) included foxes from North America. Adverse effects of dietary exposure to POPs on the immune and other organ systems have been documented in experimentally exposed Arctic foxes (Sonne et al. 2008; Sonne, Wolkers, Leifsson et al. 2009; Sonne, Wolkers, Riget et al. 2009). Given the high trophic level of Arctic foxes dependent on marine food resources, some wild Arctic foxes may accumulate dietary contaminants at levels where adverse effects may be anticipated (Klobes et al. 1998; Fuglei et al. 2007; Andersen et al. 2015).

In the current study, we measured POP levels in fat and ratios of stable isotopes of carbon and nitrogen in muscle from Pribilof foxes from St. Paul and St. George islands in order to test the following predictions. First, we examined POP levels between sexes, age classes, islands and access to anthropogenic food resources. We predicted that adult female foxes would have lower tissue concentrations of POPs than adult males or juveniles because of contaminant offloading by reproductive females to their offspring. We predicted that levels of most POPs would be higher in foxes from St. Paul, which are more reliant on northern fur seals as a food resource than foxes from St. George, which rely more on seabirds. However, we predicted that some foxes that were more reliant on anthropogenic food resources would have lower tissue concentrations of some POPs. We further investigated whether stable isotopes of carbon and nitrogen could help elucidate differences in fox diets. Given the foxes' diets and the location of the Pribilof Islands in the Bering Sea, we predicted that Pribilof foxes would have tissue levels of POPs high enough to potentially be a health concern which would present an additional challenge in the conservation of this endemic subspecies.

\section{Materials and methods}

\section{Sample collection}

Fat and muscle samples were obtained from dead foxes that were salvaged opportunistically. These included foxes that had been hit by automobiles, killed incidentally by seals while foraging on rookeries, and shot or trapped by local townspeople. Whenever possible, foxes were necropsied or frozen shortly after death. Time of death was estimated by state of the carcass (e.g., rigor mortis at the time salvaged), or by a veterinary pathologist during necropsy. Because necrosis rapidly affects fat and muscle, most foxes included in these analyses were salvaged within 48 hours after death. However, because winter temperatures on the Pribilof Islands remain below freezing throughout the day, in some instances foxes that were frozen on site immediately following death were salvaged $2-5$ days after death. 
Upon discovery, foxes were assigned a unique field collection number. Salvage date and location of death were recorded, and dead foxes were frozen whole or necropsied immediately by a veterinary pathologist (T. Spraker) and the field princial investigator (PAW). For each specimen, a $1 \times 1 \mathrm{~cm}$ sample of subcutaneous fat was removed from over the dorsoposterior region. Where dorso-posterior fat was not available, fat was obtained from the mid-ventral musculature or the abdominal cavity. Because only one fat sample was collected per animal, fat collected from different body areas was not tested for differences in lipid or POP levels; however, adipose depots (superficial, intra-abdominal and intramuscular) in polar bears have been found not to differ significantly in POP levels and patterns, with the exception of intramuscular fat from the neck (Verreault et al. 2006). Prior to sample collection, a 2-3 mm layer of fat was cut away using a sterilized scalpel to expose uncontaminated tissue for sampling. Fat samples were excised with a second sterilized scalpel, wrapped in a $6 \times 6$ inch Teflon-coated sheet, placed into a labelled plastic bag and immediately frozen, then shipped on dry ice to the NWFSC for analysis.

Muscle samples for stable isotopes were obtained from the gluteus region. Similar to fat sampling, a 2 $3 \mathrm{~mm}$ layer of muscle was removed prior to tissue collection to expose uncontaminated tissue. A $1 \times 1 \mathrm{~cm}$ sample of muscle was then excised and immediately frozen in a labelled glass vial for shipment to NWFSC.

During necropsy, foxes were sexed, weighed, examined for overall physical condition at time of death and assigned to age class. Foxes that showed any evidence of disease or obvious signs of nutritional stress (e.g., emaciation) were excluded from the study. Body condition was judged as fair to excellent based on several variables including amount of fat present, condition of the coat and teeth, pregnancy or lactation in females and presence of wounds or broken bones. Reproductive history of females was determined by evidence of lactation and/or the presence of attachment scars in the uterine horns. Cause of death was determined whenever possible. Age was determined as follows: for pups and juveniles $(<1$ year old), age was determined by tooth eruption patterns, body size and breeding season data from the Pribilof Islands (White 1992). For adult foxes (1 year or older), an upper canine tooth was carefully removed, dried and, for all but year 2006 samples, sent to a tooth-aging laboratory (Matson's Laboratory, Milltown, MT, USA) that utilizes a species-specific standardized cementum aging model to age animals to year (Bradley et al. 1981).

Data from prior radio-telemetry and tagging studies were used to establish movement and feeding patterns of foxes from different geographic areas on
St. Paul (White 1992, 2001, 2010). Radio-telemetry was conducted during summer months (May through October) and consisted of triangulating hand-held $\mathrm{H}$-antennae signals and subsequent visual confirmation of location, and remote stations that automatically recorded proximity of radio-tagged foxes. Ear tags (plastic, coloured roto-tags in both ears) were permanent markers used to identify individual foxes during both summer and winter field visits during which resighting efforts were conducted island-wide. Observed movement and feeding patterns were used to infer food habits for untagged foxes on both islands, e.g., untagged foxes that were found dead on rookeries were assumed to have utilized seals as their primary food resource. Probability of untagged foxes having access to human food resources was based on telemetry and tagging studies that quantified the distances that foxes travelled when searching for food.

Anthropogenic foods were defined as table scraps (processed and store-bought foods), pet (domestic cat) food and household garbage. In addition, commercial fishing activities on St. Paul and St. George islands at times provided foxes in the harbour areas with excessive quantities of naturally-occurring food items, e.g., crab, halibut (Hippoglossus stenolepis) and pollock (Gadus chalcogrammus). Foxes' access to anthropogenic food resources was categorized as follows: those categorized as 'high' lived in town or at the dump on each island; those categorized as 'possible' lived within $2 \mathrm{~km}$ of town and occasionally visited town as determined through radio-telemetry and tag resightings; those categorized as 'low' lived more than $4 \mathrm{~km}$ outside of town and, based on radiotelemetry and tagging studies, were considered unlikely to visit the town or dumps.

\section{Sample analyses}

\section{POPs analysis}

Analysis of POPs in fat samples for a suite of compounds including DDTs (reported as $\Sigma D D T s$ ), chlordanes ( $\Sigma \mathrm{CHLs}$ ), hexachlorocyclohexanes ( $\Sigma \mathrm{HCHs}$ ), $\mathrm{HCB}$ as well as other organochlorine pesticides and 44 individual PCB congeners ( $\sum$ PCBs) was carried out by GC/MS at NWFSC. The analytical method used is detailed by Sloan et al. (2005) and summarized here.

Pribilof fox fat samples $(0.6-1.3 \mathrm{~g})$ were weighed and extracted after the addition of surrogate standards (PCB 103), either by homogenizing with sodium sulphate and methylene chloride, or by pressurized solvent extraction using methylene chloride with sodium and magnesium sulphate. Surrogate standard recoveries were similar with either extraction method. An aliquot of the extract was removed for gravimetric lipid determination and quantification of lipid classes by TLC/FID, summarized below. 
The sample extract was filtered through a column of silica gel and alumina and concentrated for further cleanup. A second surrogate was added in order to calculate the portion of the total sample subsequently analysed, and size-exclusion chromatography with high-performance lipid chromatography was used to separate the analytes of interest from the earlier-eluting lipids. The fraction containing the POPs was collected and concentrated, and a gas chromatography internal standard was added before analysis by quadrupole GC/MS (Agilent, model 5972 or 5973) in selected-ion monitoring mode on a $60 \mathrm{~m}$ DB-5 (Agilent/J\&W Scientific) analytical column.

Analyte concentrations were calculated using the surrogate standard, either with a second order or point-topoint calibration based on 5-10 concentration levels of standards analysed with each sample batch. Summed DDTs ( $\Sigma D D T s)$ were determined by summing the concentrations of $o, p^{\prime}-\mathrm{DDD}, p, p^{\prime}-\mathrm{DDD}, o, p^{\prime}-\mathrm{DDE}, p, p^{\prime}-\mathrm{DDE}$, $o, p^{\prime}$-DDT and $p, p^{\prime}$-DDT. Summed chlordanes ( $(\mathrm{CHLs})$ was the sum of the concentrations of cis-chlordane, trans-chlordane, cis-nonachlor, trans-nonachlor, nonachlor III, heptachlor, heptachlor epoxide and oxychlordane. Summed HCHs ( $\mathrm{LHCHs}$ ) was the sum of the concentrations of $\alpha-\mathrm{HCH}, \beta-\mathrm{HCH}$ and $\gamma-\mathrm{HCH}$ (lindane). Summed PCBs ( $\Sigma$ PCBs) were calculated by summing the concentrations of 44 commonly detected chlorobiphenyl congeners present as 40 chromatographic peaks (congeners 17, 18, 28, 31, 33, 44, 49, 52, $66,70,74,82,87,95,99,101 / 90,105,110,118,128,138 /$ $163 / 164,149,151,153 / 132,156,158,170,171,177,180$, $183,187,191,194,195,199,205,206,208,209$ ) (Ballschmiter et al. 1992). Summed polybrominated diphenyl ethers ( $\angle$ PBDEs) were determined in a subset of samples as methodology was updated, and were calculated by summing the concentrations of BDE congeners $28,47,49,66,85,99,100,153,154,155$ and 183 (labelled according to the same scheme as the Ballschmiter congener designations for chlorinated biphenyls). Concentrations of other chlorinated pesticides (i.e., HCB, aldrin, dieldrin, mirex, endosulphan I) were also determined.

Quality assurance measures included the analysis of a SRM of pilot whale blubber, SRM 1945 (National Institute of Standards and Technology, Gaithersburg, MD, USA) and a laboratory blank with each batch of 10 to 12 samples, and participation in interlaboratory comparison exercises for analyses of POPs in a variety of environmental matrices, including marine mammal tissue. Surrogate standards were added at the beginning of the procedure to follow analyte recoveries throughout the extraction and were used to calculate analyte concentrations. Surrogate recoveries ranged from $97-120 \%$. LOQs were calculated based on the area of the lowest level calibration standard (Sloan et al. 2005), and ranged from 0.8 to ca. $9.5 \mathrm{ng} / \mathrm{g}$ wet weight for individual POPs, depending on the response of the analyte and the sample mass. Certain pesticides (e.g., cis-nonachlor, aldrin, endosulphan I) had LOQ values that were greater than $5 \mathrm{ng} / \mathrm{g}$ wet weight in some samples; the LOQ values for all other analytes were $<5 \mathrm{ng} / \mathrm{g}$ wet weight. Values for individual analytes measured in the SRMs were between $78-129 \%$ of the National Institute of Standards and Technology certified values, and the SRMs and laboratory blanks met all internal laboratory quality assurance criteria (Sloan et al. 2006).

\section{Lipid class analysis}

Fat samples from Pribilof foxes were analysed for percent lipid and lipid classes by TLC-FID using an Iatroscan Mark 6 (Iatron Laboratories) as described by Ylitalo et al. (2005). Each lipid sample extract was spotted on a Chromarod (Type SIII) and developed in a solvent system containing 60:10:0.02 hexane:diethyl ether:formic acid ( $\mathrm{v} / \mathrm{v} / \mathrm{v})$. Various classes of lipids (i.e., wax esters, triglycerides, free fatty acids, cholesterol and polar lipids) were separated based on polarity, with the nonpolar compounds (i.e., wax esters) eluting first, followed by the more polar lipids (i.e., phospholipids). Data were acquired and analysed using Tdatascan software (RSS Inc.). A four-point linear external calibration was used for quantitation. Duplicate TLC-FID analyses were performed for each sample extract, and the mean value for each lipid class was reported as percentage of the total lipid (Supplementary Table S5).

\section{Stable isotopes of carbon and nitrogen}

Pribilof fox muscle samples were analysed for ratios of stable isotopes of carbon and nitrogen at NWFSC. Muscle samples were freeze-dried overnight in a Virtis Freezemobile 12XL freeze-drier and the freeze-dried material was then pulverized to a powder in a SPEX Sample Prep 5100 micro ball mill (SPEX SamplePrep LLC). Homogenized samples were prepared for analysis by loading $0.4-0.6 \mathrm{mg}$ dried powder into tin cups and combusting in a Costech elemental analyser attached to a Thermo-Finnigan Delta Plus isotope ratio mass spectrometer. The values were calibrated against internal laboratory standards (aspartic acid and ${ }^{15} \mathrm{~N}$-enriched histidine) that were analysed after every 10 samples. Unenriched histidine was also analysed after every 25 samples as a control material to determine set-to-set reproducibility. Standards were acquired from SigmaAldrich. For quality control, all standards and the reference material met standard deviations of $\leq 0.3 \%$ for $\delta^{15} \mathrm{~N}$ and $\leq 0.2 \%$ for $\delta^{13} \mathrm{C}$.

Stable isotope ratios are expressed in $\delta$ notation as per mil (\%) by the following expression:

$$
\delta \mathrm{Z}=\left[\left(\mathrm{R}_{\text {sample }} / \mathrm{R}_{\text {standard }}\right)-1\right],
$$


where $\mathrm{Z}$ is ${ }^{15} \mathrm{~N}$ or ${ }^{13} \mathrm{C}$ and $\mathrm{R}_{\text {sample }}$ is the ratio ${ }^{15} \mathrm{~N} /{ }^{14} \mathrm{~N}$ or ${ }^{13} \mathrm{C} /{ }^{12} \mathrm{C}$ for the tissue sample. $\mathrm{R}_{\text {standard }}$ is the ratio ${ }^{15} \mathrm{~N} /{ }^{14} \mathrm{~N}$ or ${ }^{13} \mathrm{C} /{ }^{12} \mathrm{C}$ of the corresponding standard; atmospheric air and PeeDee Belemnite limestone, respectively.

In order to facilitate comparisons to previously published reports, the samples were not lipidextracted, though this is known to affect carbon stable isotope values, as lipids are relatively enriched in ${ }^{12} \mathrm{C}$ compared to protein (Hobson 1995). Since a few muscle $\mathrm{C}: \mathrm{N}$ ratios were $>3.5$, indicating possible higher lipid content, $\delta^{13} \mathrm{C}$ values were normalized for lipid content using the Post et al. (2007) equation for aquatic organisms prior to statistical tests. Quality assurance measures for stable isotopes included the analysis of both continuing calibration standards and a fish tissue, SRM 1946 (National Institute of Standards and Technology, Gaithersburg, MD, USA) with each batch of samples. Continuing calibration standards were run between every 10 samples, whereas SRM 1946 was run between every 20 samples. Isotope values for continuing calibration standards and SRM 1946 were within $0.30 \%$ of the values calibrated against international standards for $\delta^{15} \mathrm{~N}$ and within $0.20 \%$ for $\delta^{13} \mathrm{C}$. All samples were analysed in replicate, and the values averaged.

\section{Statistical analyses}

If the concentration of an individual POP was below the LOQ in a sample, a value of LOQ/2 was used for that analyte to calculate sums (e.g., $\Sigma$ PCBs, $\Sigma D D T$, $\Sigma$ CHLs). Lipid-adjusted POP concentrations, using the gravimetric lipid results, were log-transformed to achieve normality, and total lipid was similarly arcsine-transformed for ANOVA (Zar 1984). ANOVA was performed to evaluate POPs by analyte class, stable isotope values and total lipid with respect to age class, sex, island, access to anthropogenic foods and body condition. Tukey's HSD test was used to determine post-hoc pairwise significant differences in mean POP concentrations (by analyte class), lipid and stable isotope values within covariate groups. PCA was performed by summed analyte class $(n=50)$ (Supplementary Tables S2, S3), and by analyte class with stable isotope values $(n=39)$ using a correlation matrix. Components that explained more than $10 \%$ of the variance were retained. Varimax factor loadings were run to evaluate the loading weights of the individual analyte classes and stable isotopes (range: $0-1.0$ ); values greater than 0.5 are reported. GLMs were performed to evaluate retained PCA components. Full models are reported, including sex, age class (adult vs. juvenile/pup), island and access to anthropogenic foods as covariates. All models were conducted in $\mathrm{R}$ (version 3.2.2, $\mathrm{R}$ Development Core Team 2015). The level of significance used for all statistical tests was alpha $=0.05$.

\section{Results}

\section{Lipid content and POP concentrations}

Demographic data on the Pribilof foxes sampled as part of this study are given in Supplementary Table S1, along with the full results of the chemical analyses, including lipid, lipid classes, individual POPs concentrations and stable isotopes of carbon and nitrogen (Supplementary Table S5; full metadata provided in Supplementary Table S6). Samples were collected between 1999 and 2006, with all age classes represented. All foxes were in fair to excellent body condition; foxes in poor condition were excluded from this study.

A summary of the lipids, POP levels and stable isotopes by covariate is given in Tables 1 and 2. Lipid content of Pribilof fox adipose (fat) samples was highly variable, with values ranging from 16 to $96 \%$. Lipids in Pribilof fox fat tissue were predominantly triglycerides, with small percentages of free fatty acids in some samples, indicating a small degree of tissue decomposition (Supplementary Table S5).

Concentrations of POPs in fat of Pribilof foxes were highly variable, and ranked $\Sigma \mathrm{PCBs}>\Sigma \mathrm{CHLs} \gg \Sigma \mathrm{HCH}$ $>$ EDDTs $>\mathrm{HCB} \sim \sum$ PBDEs (Table 1). The most abundant $\mathrm{PCB}$ congeners measured in the fox samples were the hexachlorinated PCBs 138 and 153, the heptachlorinated PCBs 170 and 180 and the octachlorinated PCB 194, accounting for $69-87 \%$ of $\Sigma$ PCBs (Fig. 1). The triand tetrachlorinated PCBs (i.e., PCBs 17, 18, 28, 31, 33, $44,49,52,66,70$ and 74) were minor contributors to SPCBs, making up less than $2 \%$ of the total (Supplementary Table S5). The composition pattern of individual PCB congeners in Pribilof foxes showed that PCB 153 was the most abundant congener of the PCB congeners measured (Supplementary Fig. S1a). One notable exception was the PCB composition pattern of a young adult female fox from St. Paul that differed by having much higher percentages of PCBs 170, 180, 194 and 206 compared to PCB 153 (Supplementary Fig. S1b). For $\Sigma D D T s, p, p$-DDE was the most abundant DDT, contributing $92-100 \%$ to the total. Oxychlordane and trans-nonachlor together contributed $81-96 \%$ to the $\Sigma \mathrm{CHLs}$. The most abundant $\mathrm{HCH}$ isomer was $\beta-\mathrm{HCH}$, which contributed $86-100 \%$ of $\sum \mathrm{HCH}$. PBDE 47 was the predominant PBDE congener measured in fox samples that had detectable concentrations of these compounds, contributing $62-100 \%$ to $\Sigma$ PBDEs.

The ANOVA showed that mean concentrations of ¿PCBs, $\Sigma$ CHLs, $\Sigma$ HCHs and $2 D D T$ s were significantly higher in males than in females (Table 1), and post-hoc Tukey HSD showed foxes with a low or possible probability of access to anthropogenic foods also had higher mean $\sum$ DDTs compared to those with a high probability of access (Table 1). Mean HCB concentration was significantly higher in foxes from St. George, but 2 CHLs were significantly higher on St. Paul. No statistical 


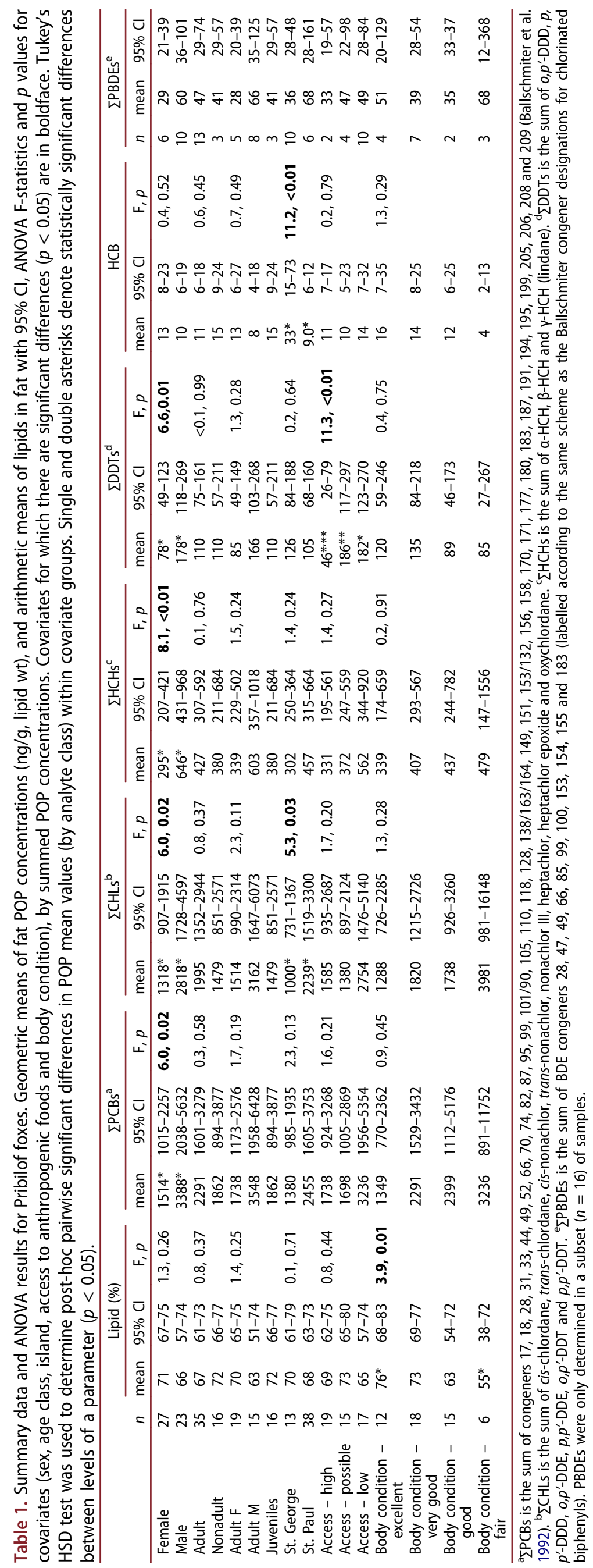


Table 2. Summary data and ANOVA results for Pribilof foxes. Arithmetic means of stable isotope values of carbon and nitrogen (\%o) in muscle with $95 \%$ confidence intervals $(\mathrm{Cl})$, and ANOVA F-statistics and $p$ values for covariates (sex, age class, island, access to anthropogenic foods and body condition), by stable isotope values. Covariates for which there are significant differences $(p<0.05)$ are in boldface. Tukey's HSD test was used to determine post-hoc pairwise significant differences in mean values within covariate groups. Single and double asterisks denote statistically significant differences between levels of a parameter $(p<0.05)$.

\begin{tabular}{|c|c|c|c|c|c|c|c|}
\hline & \multirow[b]{2}{*}{$n$} & \multicolumn{3}{|c|}{$\delta^{13} C(a q)^{a}$} & \multicolumn{3}{|c|}{$\delta^{15} \mathrm{~N}$} \\
\hline & & mean & $95 \% \mathrm{Cl}$ & $\mathrm{F}, p$ & mean & $95 \% \mathrm{Cl}$ & $\mathrm{F}, p$ \\
\hline Female & 22 & -19 & $-19.5--18.5$ & $<0.1,0.91$ & $14.8^{*}$ & $13.9-15.7$ & $6.1,0.02$ \\
\hline Male & 17 & -19 & $-19.7--18.4$ & & $16.3^{*}$ & $15.6-17.1$ & \\
\hline Adult & 26 & -18.9 & $-19.4--18.5$ & $0.5,0.48$ & 15.7 & $14.9-16.4$ & $0.8,0.37$ \\
\hline Nonadult & 13 & -19.1 & $-19.8--18.5$ & & 15.1 & $13.9-16.2$ & \\
\hline Adult $\mathrm{F}$ & 15 & -19 & $-19.5--18.5$ & $0.3,0.73$ & 15.2 & $14.0-16.3$ & $1.6,0.21$ \\
\hline Adult $\mathrm{M}$ & 11 & -18.8 & $-19.7--18.0$ & & 16.4 & $15.5-17.3$ & \\
\hline Juveniles & 13 & -19.1 & $-19.8--18.5$ & & 15.1 & $13.9-16.2$ & \\
\hline St. George & 13 & -19.3 & $-20.1--18.5$ & $1.1,0.31$ & 16.1 & $15.0-17.1$ & $1.8,0.18$ \\
\hline St. Paul & 26 & -18.8 & $-19.3--18.4$ & & 15.2 & $14.4-15.9$ & \\
\hline Access: high & 16 & $-18.7^{* *}$ & $-19.0--18.4$ & $4.8,0.01$ & $14.2^{*}$ & $13.6-14.8$ & $8.5,<0.01$ \\
\hline Access: possible & 8 & $-19.8^{* * *}$ & $-20.9--18.7$ & & 15.6 & $13.9-17.3$ & \\
\hline Access, low & 15 & $-18.9^{*}$ & $-19.5--18.2$ & & $16.8^{*}$ & $15.9-17.6$ & \\
\hline Body condition: excellent & 8 & -19.4 & $-20.1--18.8$ & $2.3,0.10$ & 15.8 & $14.3-17.2$ & $2.6,0.07$ \\
\hline Body condition: very good & 13 & -18.6 & $-19.0--18.2$ & & 16.2 & $15.3-17.0$ & \\
\hline Body condition: good & 14 & -19.3 & $-20.1--18.4$ & & 14.4 & $13.4-15.4$ & \\
\hline Body condition: fair & 4 & -18.4 & $-19.4--17.3$ & & 16.5 & $14.1-19.0$ & \\
\hline
\end{tabular}

${ }^{a}$ Carbon stable isotope values were normalized for lipid content according to the method of Post et al. (2007) for aquatic organisms.

differences in POPs were seen with respect to body condition category, though total lipid values varied significantly (Table 1). As expected, foxes judged as being in very good or excellent condition had higher lipid levels in their fat than foxes judged as being in good or fair condition. Age class was not a significant factor for any POPs.

\section{Stable isotopes}

Carbon isotope values ranged from $-21.76 \%$ to $17.32 \%$. Carbon isotope values were significantly more depleted in foxes judged as having possible access to anthropogenic foods compared to those with a low or high probability of access (Table 2). Nitrogen stable isotope values ranged from $11.04 \%$ to $18.97 \%$, and were significantly higher $(p<0.02)$ in males than in females (Table 2, Fig. 2). Nitrogen stable isotope values were also significantly higher in foxes with a low probability of access to anthropogenic food resources compared to foxes with a high probability of access $(p<0.01)$ (Table 2). Foxes considered to have low probability of access to anthropogenic food resources had an average $\delta^{15} \mathrm{~N}$ value $2.6 \%$ higher than those with a high probability of access, whereas foxes considered to have possible access to anthropogenic food resources had intermediate $\delta^{15} \mathrm{~N}$ values (Table 2). There were no significant differences in stable isotope values between islands, age classes or body condition categories.

\section{Principal component analysis}

There were four extracted factors from the PCA including POP concentrations and stable isotopes that each accounted for greater than $10 \%$ of the variance in the dataset (Tables 3 and 4). Factor 1 accounted for $48 \%$ of the variance, with high loadings for $\Sigma$ PCBs, $\Sigma$ CHLs and $\Sigma$ HCHs (Table 3). The GLM for this factor showed a statistical increase in Factor 1 for males compared to females (estimate, 1.53; $p<0.01)$; for foxes on St. Paul compared to St. George (estimate, 1.88; $p<0.01$ ); and a statistical decrease for foxes with a high probability of access to anthropogenic foods compared with a low probability of access (estimate, $-1.47 ; p<0.05$; Table 4). Factor 2 accounted for $17 \%$ of the variance in the data set and loaded highly for $\delta^{13} \mathrm{C}$ (Table 3 ). The GLM for this factor showed a statistical increase in Factor 2 values for foxes with a high probability of access to human foods compared to low probability of access (estimate, 1.18; $p<0.01$ ). Factor 3 accounted for $15 \%$ of the variance in the model and loaded highly for HCB (Table 3). The GLM of this factor showed a statistical decrease in Factor 3 for foxes on St. Paul compared to St. George (estimate, $-1.07 ; p<0.01$; Table 4). Factor 4 accounted for $14 \%$ of the variance in the dataset, and loaded highly for

Table 3. PCA rotated component-loading weights for POPs contaminant classes and stable isotopes in Pribilof foxes $(n=39)$. Only weights $>0.5$ were reported.

\begin{tabular}{|c|c|c|c|c|}
\hline & Factor 1 & Factor 2 & Factor 3 & Factor 4 \\
\hline$\%$ variance & 47.7 & 16.9 & 15.0 & 13.7 \\
\hline eigenvalue & 3.3 & 1.2 & 1.1 & 1.0 \\
\hline$\Sigma \mathrm{PCBs}$ & 0.58 & & & \\
\hline$\sum \mathrm{CHLS}$ & 0.58 & & & \\
\hline$\sum \mathrm{HCHs}$ & 0.57 & & & \\
\hline$\sum \mathrm{DDT}$ & & & & 0.64 \\
\hline $\mathrm{HCB}$ & & & 0.95 & \\
\hline$\delta^{13} \mathrm{C}^{\mathrm{a}}$ & & 0.90 & & \\
\hline$\delta^{15} \mathrm{~N}$ & & & & 0.77 \\
\hline
\end{tabular}




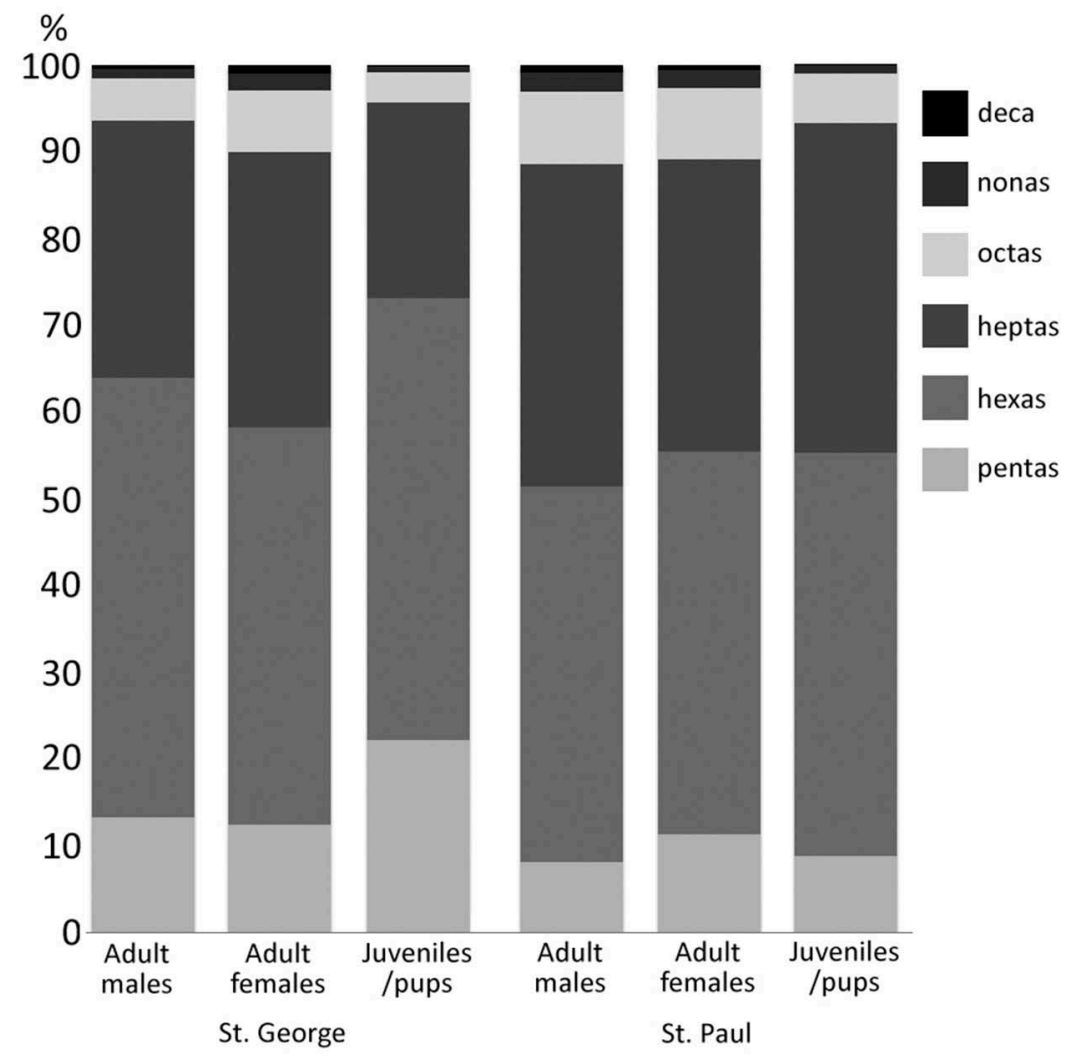

Figure 1. Proportions of PCB congeners by homolog group (chlorination level) in adult male, adult female and juvenile/pup Pribilof foxes from St. Paul and St. George islands. Tri-and tetra-chlorinated congeners made an insignificant contribution $(<2 \%)$ to the totals and are not shown.

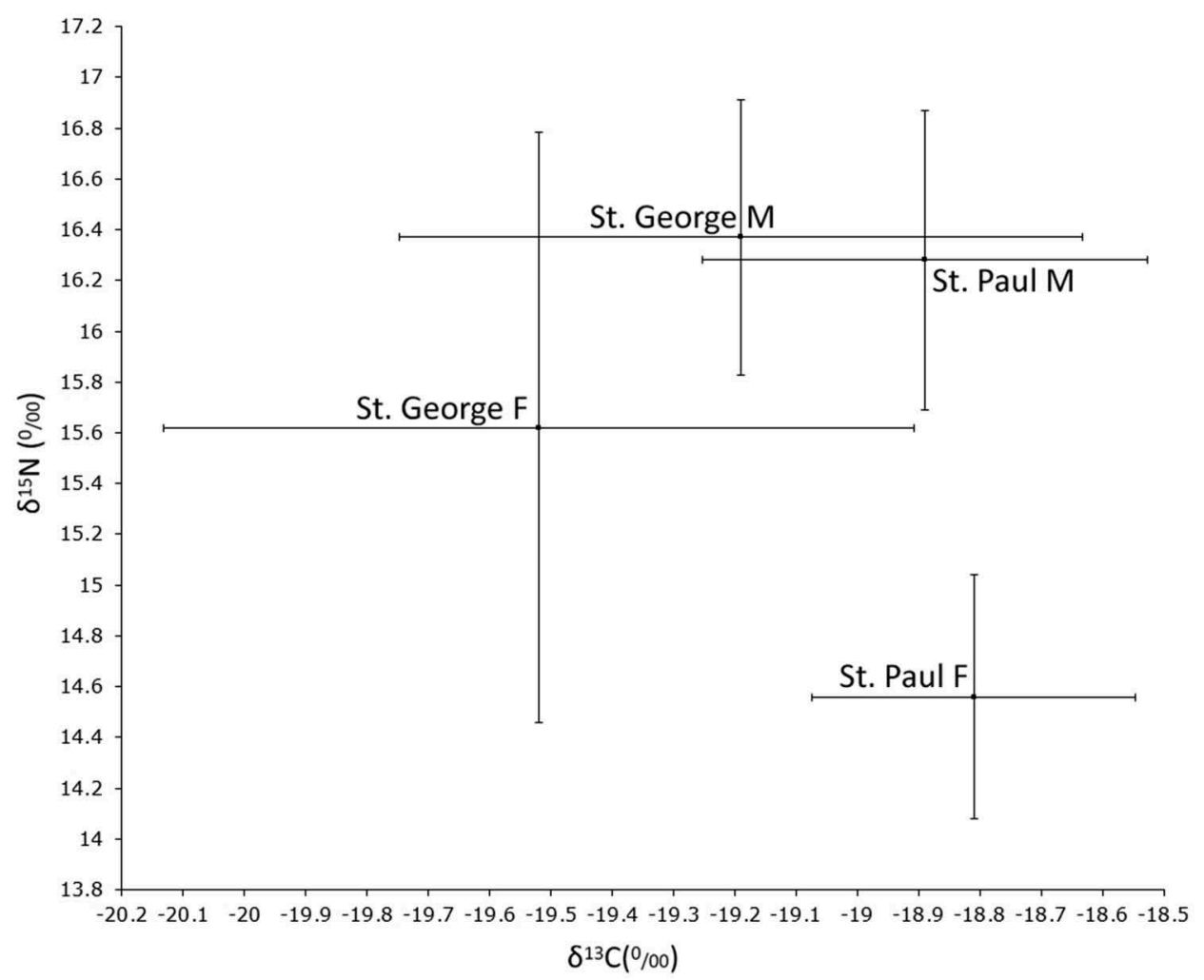

Figure 2. Nitrogen $\left(\delta^{15} \mathrm{~N}\right)$ vs. carbon $\left(\delta^{13} \mathrm{C}\right)$ stable isotope values (\%o) in Pribilof foxes by sex and island. Error bars are standard error. For both islands combined, males had significantly higher $\delta^{15} \mathrm{~N}$ values than females $(16.3 \%$ vs. $14.8 \%$; $p=0.02)$. 
Table 4. Full GLM parameters and coefficients for PCA Factors 1 to 4 for POPs and stable isotopes in Pribilof foxes $(n=39)$. Age class (adult vs. juvenile/pup), sex, island and access to human foods were included as potential covariates. Covariates for which there are significant differences $(p<0.05)$ are in boldface.

\begin{tabular}{|c|c|c|c|c|}
\hline & \multirow[b]{2}{*}{ Model } & \multirow[b]{2}{*}{ Estimate } & \multirow{2}{*}{$\frac{\text { Standard }}{\text { error }}$} & \multirow[b]{2}{*}{$p$ value } \\
\hline & & & & \\
\hline \multirow[t]{6}{*}{ Factor 1} & Intercept & -0.92 & 0.58 & 0.125 \\
\hline & Sex (male) & 1.53 & 0.50 & 0.004 \\
\hline & Island (St. Paul) & 1.88 & 0.59 & 0.003 \\
\hline & Access (high vs. low) & -1.47 & 0.61 & 0.023 \\
\hline & Access (possible vs. low) & -0.65 & 0.72 & 0.378 \\
\hline & Age class (adult vs. nonadult) & -0.79 & 0.57 & 0.171 \\
\hline \multirow[t]{6}{*}{ Factor 2} & Intercept & -0.27 & 0.35 & 0.939 \\
\hline & Sex (male) & -0.14 & 0.30 & 0.640 \\
\hline & Island (St. Paul) & -0.32 & 0.35 & 0.368 \\
\hline & Access (high vs. low) & 1.18 & 0.37 & 0.003 \\
\hline & Access (possible vs. low) & -0.74 & 0.43 & 0.096 \\
\hline & Age class (adult vs. nonadult) & -0.10 & 0.34 & 0.771 \\
\hline \multirow[t]{6}{*}{ Factor 3} & Intercept & 0.97 & 0.38 & 0.015 \\
\hline & Sex (male) & -0.26 & 0.32 & 0.424 \\
\hline & Island (St. Paul) & -1.07 & 0.38 & 0.007 \\
\hline & Access (high vs. low) & -0.21 & 0.40 & 0.596 \\
\hline & Access (possible vs. low) & -0.21 & 0.47 & 0.661 \\
\hline & Age class (adult vs. nonadult) & -0.032 & 0.37 & 0.931 \\
\hline \multirow[t]{6}{*}{ Factor 4} & Intercept & 0.78 & 0.37 & 0.044 \\
\hline & Sex (male) & -0.11 & 0.32 & 0.736 \\
\hline & Island (St. Paul) & -0.73 & 0.37 & 0.060 \\
\hline & Access (high vs. low) & -0.5 & 0.40 & 0.212 \\
\hline & Access (possible vs. low) & -0.68 & 0.46 & 0.150 \\
\hline & Age class (adult vs. nonadult) & -0.29 & 0.36 & 0.424 \\
\hline
\end{tabular}

both $\sum$ DDTs and $\delta^{15} \mathrm{~N}$ (Table 3). The GLMs for Factor 4 suggested that foxes on St. Paul had overall lower values for Factor 4 than foxes from St. George, however, the $p$ value (0.06) exceeded the 0.05 level of significance (Table 4).

\section{Discussion}

This is the first study to report concentrations of POPs or stable isotope values in tissues of Pribilof foxes. Because the analyses were conducted on tissues of foxes collected 10 to 15 years ago and inputs of POPs to marine waters are predicted to change with environmental conditions, e.g., increasing temperatures (Burek et al. 2008), these findings also represent a baseline of contaminant concentrations in the region.

\section{POP levels and stable isotope values}

The general patterns and levels of POPs in Pribilof foxes were consistent with those reported in coastal ecotype Arctic foxes from other regions that are relatively more dependent on marine food resources (Fuglei et al. 2007; Geffen et al. 2007), in particular, foxes from Svalbard and Iceland (Norheim 1978; Wang-Andersen et al. 1993; Klobes et al. 1998; Fuglei et al. 2007; Andersen et al. 2015). Similar to Pribilof foxes, $p, p$ '-DDE was the most abundant DDT in Svalbard and Iceland Arctic fox tissues, where $p, p^{\prime}-$
DDE was the only DDT reported (Klobes et al. 1998; Fuglei et al. 2007; Andersen et al. 2015).

PCB homolog profiles (see Fig. 1) in Pribilof foxes were similar to those reported in previous studies of PCBs in Arctic foxes where comparable numbers of PCB congeners were measured (Hoekstra et al. 2003; Fuglei et al. 2007). As in previous studies, the more highly chlorinated PCB congeners (those containing six or more chlorine atoms) dominated the $\mathrm{PCB}$ profiles of Pribilof foxes (Fig. 1; Supplementary Fig. S1a). Homolog profiles of Pribilof foxes were very comparable between age classes and islands (Fig. 1). Though it appears that adult foxes have a slightly larger proportion of PCB 209 compared to non-adults, this was not statistically significant $(p=0.06)$. The composition pattern of individual PCB congeners in Pribilof foxes normalized to PCB 153 (Supplementary Fig. S1a) is closely comparable to Arctic foxes from North America reported by Hoekstra et al. (2003). PCB 153, a congener that has been shown to be recalcitrant to metabolism in some marine mammals (Boon et al. 1994), was the most abundant congener measured in Pribilof foxes. The exception was one young adult female (D-01-05) from St. Paul with a very unusual pattern (Supplementary Fig. S1b). This fox, noted to be in very good body condition at time of death when struck by a car, had much higher percentages of certain hepta- through nonachlorinated PCB congeners compared to all other foxes examined in our study (Supplementary Fig. S1b). While there is no obvious physical explanation for this fox's unusual PCB pattern, this fox had low probability of access to anthropogenic food resources. Therefore, one possible explanation is that D-01-05 consumed an individual prey item (e.g., seal) containing a higher proportion of highly chlorinated congeners that had disseminated to various tissues of the fox (i.e., fat) but had not yet been metabolized. Arctic foxes are inferred to have a capacity to metabolize certain POPs, such as PCBs and chlordanes, similar to that of polar bears. Both species exhibit similar patterns of more highly-chlorinated PCB congeners and other recalcitrant POPs in their tissues, and these patterns differ from those in their prey and in other marine predators (Hoekstra et al. 2003; Fuglei et al. 2007), i.e., pinnipeds. Analyses of blubber samples from northern fur seal pups from the Pribilofs found that PCBs 138, 153, 170 and 180 accounted for only $32 \%$ of $\Sigma$ PCBs (PCB 194 was not measured), while $p, p$ 'DDE contributed $90 \%$ to $\Sigma$ DDTs (Loughlin et al. 2002). Likewise, in ringed seals from near $\mathrm{Pt}$. Barrow, Alaska, PCBs 153, 138, 170, 180 and 194 contribute $45-50 \%$ of $\Sigma$ PCBs, oxychlordane and trans-nonachlor together contributed $79-86 \%$ of total chlordanes, while p,p'-DDE made up $78-85 \%$ of $\mathrm{DDDTs}$ (Kucklick et al. 2002). Proportions of these 
relatively recalcitrant POPs in both of these pinniped species were lower than those found in Pribilof foxes, suggesting Pribilof foxes are better able to metabolize many of the POPs than pinnipeds.

Pribilof foxes had higher concentrations of $\mathrm{SHCHs}$ than marine mammals from Arctic regions further to the east. This geographic pattern in $\mathrm{HCH}$ distribution has been reported previously (AMAP 1998; Muir \& Norstrom 2000; Hoekstra et al. 2002; de Wit et al. 2004), and reflects the greater exposure of marine wildlife to $\mathrm{HCHs}$ in the north-eastern Pacific (i.e., Alaska) as a result of proximity to areas where $\mathrm{HCHs}$ were more recently used (e.g., Asia; Iwata et al. 1993) compared with areas such as Greenland and Iceland.

Island was a significant factor in the GLMs for Factor 1, which loaded highly for 2 PCBs, $\Sigma$ CHLs and $\mathrm{LHCHs}$ (Tables 3 and 4). For example, foxes from St. Paul had higher mean values of $\Sigma$ PCBs (2455 ng/g lipid wt) compared with foxes from St. George (1380 ng/g lipid wt), which may relate to differences in PCB contamination among prey items, and reflect the reliance of St. Paul foxes on fur seals, and St. George foxes on seabirds and their eggs. This is supported by previous studies that found mean concentrations of $\sum$ PCBs of $4334 \mathrm{ng} / \mathrm{g}$ lipid wt in blubber of northern fur seal pups from St. George, much higher than the mean of $1609 \mathrm{ng} / \mathrm{g}$ lipid wt in fur seal pups from St. Paul (Loughlin et al. 2002). The differences in observed POP levels between St. Paul and St. George northern fur seals were attributable to differences in foraging habitat (Robson et al. 2004). If foxes on St. George were dependent on northern fur seals as a food resource to the same extent as foxes on St. Paul, they would be expected to have higher PCB concentrations than St. Paul foxes, however our findings showed the opposite trend. In contrast, seabird eggs from St. George contain lower concentrations of $\Sigma$ PCBs compared with levels in northern fur seals, with $695 \mathrm{ng} / \mathrm{g}$ lipid wt in common murre (Uria aalge) eggs and $876 \mathrm{ng} / \mathrm{g}$ lipid wt in thick-billed murre ( $U$. lomvia) eggs (Vander Pol et al. 2004). Murres are the most numerous seabirds nesting in the Pribilof Islands. Likewise, concentrations of $\Sigma$ CHLs in Pribilof foxes were significantly higher $(p=0.03)$ on St. Paul Island compared to St. George Island (Table 1), again reflecting differences in fox diets. Reported concentrations of $\Sigma$ CHLs are much lower in St. George seabird eggs (133 ng/g lipid wt in common murre and $94 \mathrm{ng} / \mathrm{g}$ lipid wt in thick-billed murre eggs; Vander Pol et al. 2004) than in northern fur seals, which had blubber concentrations of 608-2400 ng/g lipid wt (Krahn et al. 1997).

Sex was also a significant factor in the GLMs for Factor 1, with males having higher levels of most POPs than females (Table 4). This might be explained by females offloading POPs to their offspring during gestation and lactation as observed in other marine mammal species, or by different prey preferences compared with males. Probability of access to anthropogenic foods was another significant factor in the models for Factor 1 (Table 4). Foxes with a high probability of access to anthropogenic foods had overall lower levels of most POPs compared with foxes with low probability of access, which is consistent with human garbage containing lower POP levels than highly contaminated fur seals.

Factor 2 in the PCA loaded $\delta^{13} \mathrm{C}$ (Table 3) and the GLMs showed that foxes with high probability of access to human foods had significantly higher $\delta$ ${ }^{13} \mathrm{C}$ values compared to those with a low probability of access (Table 4). Relative enrichment in ${ }^{13} \mathrm{C}$ in wildlife indirectly consuming anthropogenic foods has been observed previously. For example, peregrine falcon (Falco peregrinus) eggs (Newsome et al. 2010) from areas with dense human populations, where falcons prey heavily on urban pigeons, were much less depleted in ${ }^{13} \mathrm{C}$ than eggs from non-urbanized areas with a more diverse prey base. ${ }^{13} \mathrm{C}$ enrichment in the peregrine eggs was attributable to urban pigeons consuming more corn-based foods; corn is enriched in ${ }^{13} \mathrm{C}$ compared with grasses such as wheat (Tieszen et al. 1983). For Pribilof foxes with a low probability of access to anthropogenic foods, the carbon isotope ratios in potential prey items (e.g., seabirds and northern fur seals) are dependent on foraging area (nearshore vs. pelagic, which may vary seasonally), on latitude (which may also vary seasonally), and on trophic level (which may vary by age class). However, northern fur seal tissues tend to be more enriched in ${ }^{13} \mathrm{C}$ than those of seabirds; skin samples of northern fur seals from the Pribilofs (Kurle \& Worthy 2001) were enriched (mean $\delta^{13} \mathrm{C}$ values ranging from -16 to -17.6$)$ compared with muscle of seabirds (Ricca et al. 2008) from the Aleutians (mean $\delta^{13} \mathrm{C}$ values ranging from -17.2 for more inshore feeders to -22.4 for more pelagic feeders). The muscle $\delta^{13} \mathrm{C}$ values in foxes from St. George in our study are similar to seabird muscle values in Ricca et al. (2008) and to values reported in tissues of pelagic seabirds sampled opportunistically in the north-west Pacific (Wainright et al. 1998; Elliott 2005); lipid-rich seabird eggs show even greater depletion in ${ }^{13} \mathrm{C}$ than does muscle (Ehrich et al. 2011). Female foxes from St. George showed relative depletion in both ${ }^{13} \mathrm{C}$ and ${ }^{15} \mathrm{~N}$ compared with males (Fig. 2), although the differences were not statistically significant. There is not as much opportunity for foxes on St. George to access anthropogenic foods, however, so the slightly lower $\delta^{15} \mathrm{~N}$ and $\delta^{13} \mathrm{C}$ values may relate to female St. George foxes making more use of lower trophic-level and more terrestrial food resources, e.g., lemmings or caribou. Stable isotope values in tissues of Arctic foxes from Svalbard 
that fed on lemmings vs. marine diets showed a similar relationship (Fuglei et al. 2007), and Arctic foxes from North America reliant on lemmings were also found to be depleted in ${ }^{13} \mathrm{C}$ (Hoekstra et al. 2003; Fuglei et al. 2007, see also Supplementary Table S4 for comparisons of stables isotopes and POPs in Arctic fox tissues from various geographical areas).

Factor 3 in the PCA loaded highly for $\mathrm{HCB}$ (Table 3), which was significantly higher $(p<0.01)$ in foxes from St. George (Tables 1 and 4). Again this difference is attributable to differences in prey; $\mathrm{HCB}$ levels in seabirds nesting on St. George are orders of magnitude higher than in northern fur seals. For example, HCB levels in seabird egg composites from St. George were $679 \mathrm{ng} / \mathrm{g}$ lipid wt in common murre and $914 \mathrm{ng} / \mathrm{g}$ lipid wt in thick-billed murre, respectively (Vander Pol et al. 2004). In contrast, HCB concentrations in blubber of northern fur seals from the Pribilofs were at most $3 \mathrm{ng} / \mathrm{g}$ lipid wt in one study (Krahn et al. 1997) and $2 \mathrm{ng} / \mathrm{g}$ lipid wt in another (Loughlin et al. 2002). Thus, overall, differences in levels of HCB, $\Sigma$ CHLs and $\Sigma$ PCBs between St. Paul and St. George foxes reflect the differences in the levels of these contaminants reported in their prey items on each island and are in agreement with observations that foxes on St. Paul rely more on fur seals while those on St. George rely more on seabirds and their eggs.

Factor 4 in the PCA loaded highly for $\delta^{15} \mathrm{~N}$ and for EDDTs. The ANOVA shows that sex and access to anthropogenic foods were significant factors for $\delta^{15} \mathrm{~N}$ ( $p=0.02$ and $p<0.01$, respectively) and for $\Sigma$ DDTs ( $p=0.01$ and $p<0.01$, respectively; Tables 1 and 2), but in the GLMs for Factor 4, these associations were not apparent. It is possible the prediction capability was dispersed across covariates, particularly since Factor 4 only explained $14 \%$ of the variance in the dataset. The PCA analysis that excluded the isotope data $(n=50$; Supplementary Tables S2, S3) demonstrated a decreased association between Factor 3, which loaded highly for $\Sigma$ DDTs, and high probability of access to anthropogenic foods, compared to low probability of access $(p<0.01)$, and also for foxes from St. Paul Island compared to St. George $(p=0.017)$, while sex was not a significant factor.

Mean concentrations of several classes of POPs (i.e., $\Sigma \mathrm{PCBs}, \Sigma \mathrm{CHLs}, \Sigma \mathrm{HCHs}$, and $\Sigma \mathrm{DDTs}$ ) by ANOVA were significantly higher in adult males than in adult females. In polar bears as well as many species of odontocetes and pinnipeds, reproductive-age females generally have lower levels of POPs than juveniles, adult males or senescent females due to offloading of contaminants during gestation and lactation (Norstrom et al. 1998; Beckmen et al. 1999; Ylitalo et al. 2001; Krahn et al. 2007). Similarly, POP concentrations in tissues of male urban red foxes (Dip et al. 2003) were significantly higher than in females, although this trend has not been generally observed in Arctic foxes. Based on observational study (White 2001), a higher percentage of female Pribilof foxes living in town had pups compared with those living outside of town, suggesting that contaminant offloading would have been prevalent among town females. Though contaminant offloading by reproductive females affects comparative levels of POPs, the observed difference in $\mathrm{DDDT}$ s between adult male and female Pribilof foxes was not explained by sex alone, but was also associated with greater utilization of anthropogenic food sources. The ANOVA showed that both probability of access to anthropogenic foods and sex were significant factors for $\sum D D T$ s and $\delta^{15} \mathrm{~N}$ values. In addition, Factor 4 of the PCA loaded both $\Sigma$ DDTs and $\delta^{15} \mathrm{~N}$; $\Sigma$ DDTs did not load in Factor 1 with $\Sigma$ PCBs, $\Sigma$ CHLs, and $\Sigma \mathrm{HCH}$. Foxes with high access to anthropogenic foods were mostly females from St. Paul. These foxes had significantly lower 2 DDTs and were feeding on average nearly an entire trophic level lower than St. Paul males, and in addition had carbon stable isotope signatures that indicated they were eating foods that were enriched in ${ }^{13} \mathrm{C}$ (i.e., corn-based).

Multiple factors may complicate the interpretation of stable isotope data. The $\delta^{13} \mathrm{C}$ values observed in Pribilof foxes, while indicating an overall reliance on marine resources, may also reflect geographical differences seen at the base of the marine food web in the Bering, Chukchi and Beaufort seas (Schell et al. 1998), where a gradient has been observed in ${ }^{13} \mathrm{C}$ in zooplankton between the relatively enriched southern and central Bering Sea (e.g., the Pribilof Islands), which becomes increasingly depleted moving northward towards the northern Chukchi and western Beaufort seas (e.g., Barrow). Values of $\delta^{15} \mathrm{~N}$ at the base of the food chain may vary geographically as well (Nadelhoffer et al. 1996; Clark et al. 2006). Enrichment in ${ }^{15} \mathrm{~N}$ may also occur as a result of eutrophication of the terrestrial and nearshore ecosystems in the presence of seabird and fur seal colonies (Cabana \& Rasmussen 1996; Wainright et al. 1998). Further, POPs measurements in fat represent a different time scale compared with the stable isotopes measured in muscle; POPs levels reflect bioaccumulation of these lipophilic compounds over a relatively long time scale (i.e., years), especially for males that do not offload POPs during reproduction, while tissue turnover for stable isotopes in muscle is on the order of months (Roth \& Hobson 2000). Comparisons of stable isotope values between different tissues are also confounded by differing rates of tissue turnover. Finally, nutritional stress can contribute to elevated $\delta^{15} \mathrm{~N}$ values in some species (Hobson et al. 1993) and result in an apparent increase in 
trophic level. However, since the foxes in this study were all in fair or better condition, nutritional stress is not believed to have been a significant factor.

Pribilof foxes show relative enrichment in both ${ }^{13} \mathrm{C}$ and ${ }^{15} \mathrm{~N}$, consistent with their greater reliance on marine resources, despite the fact that some Pribilof foxes are clearly consuming terrestrial resources (i.e., lemmings, caribou) or anthropogenic foods. Though not statistically significant, there may be subtle sexbased differences in prey selection for each island, with females using relatively more inland food resources compared with males. Anthropogenic food resources altered $\delta^{15} \mathrm{~N}$ and $\delta^{13} \mathrm{C}$ values for foxes with a high probability of access, and POP and $\delta^{13} \mathrm{C}$ levels were also affected by the availability of different food resources both within and between islands. The larger human population on St. Paul vs. St. George Island (approximately 480 vs. 100 people, respectively; 2010 census) equates to larger accumulations of anthropogenic foods and more opportunities for foxes on St. Paul to scavenge table scraps, pet food and garbage. Foxes with a high probability of access to anthropogenic food sources fed at a lower trophic level overall, with lower levels of POPs, especially LDDTs, and showed the influence of corn-based foods on their carbon isotope values. Adult male foxes on St. Paul appeared to rely more on marine resources, e.g., fur seals (White 2001), with higher levels of POPs and higher $\delta^{15} \mathrm{~N}$ values. In contrast to foxes from St. Paul, foxes on St. George had POP signatures (i.e., higher HCB levels but lower levels of other POPs) and carbon stable isotope values reflecting a greater reliance on seabirds and augmented by terrestrial prey such as lemmings or caribou.

\section{POP levels and possible health effects}

Pribilof foxes bioaccumulate POPs at levels that are high enough to warrant concern about health effects. A recent review evaluated potential adverse effects of POPs on the immune system, thyroid hormones, testosterone levels, development of sexual and internal organs and bone mineral density at levels typically found in wild coastal ecotype Arctic foxes (Pedersen et al. 2015). Experimental feeding studies found that frequency of lesions in thyroid, liver and kidney were significantly higher compared to foxes fed a control diet (Sonne et al. 2008; Sonne, Wolkers, Leifsson et al. 2009; Sonne, Wolkers, Riget et al. 2009), with mean liver concentrations of exposed foxes in these studies of $2064 \mathrm{ng} / \mathrm{g}$ lipid wt for $\Sigma$ PCBs and $2223 \mathrm{ng} / \mathrm{g}$ lipid wt for $\Sigma$ CHLs, and much lower levels of other POPs. In polar bears, high PCB levels have been associated with decreased humoral immunity (Norstrom et al. 1998; Lie et al. 2004), with bears from Svalbard showing decreased antibody titers after immunization for a variety of viruses, compared with bears from Canada. Lowered plasma retinol and testosterone levels, alterations in plasma thyroid hormone levels, and reproductive system pathologies (Letcher et al. 2010) have also been described for Svalbard and East Greenland polar bears, where mean fat $\Sigma \mathrm{PCB}$ concentrations ranged from $5400-9100 \mathrm{ng} / \mathrm{g}$ lipid wt and ECHLs of $1500 \mathrm{ng} / \mathrm{g}$ lipid wt and greater. High tissue levels of some organochlorine compounds (e.g., PCBs, DDE and $\mathrm{HCHs}$ ) have been associated with cancer in other wildlife species and humans (Dich et al. 1996; Martineau et al. 2002; Randhawa et al. 2015).

All of the Pribilof foxes sampled had $\mathrm{SHCH}$ concentrations in fat that were two to 100 times higher than experimentally exposed foxes (Sonne et al. 2008; Sonne, Wolkers, Leifsson et al. 2009; Sonne, Wolkers, Riget et al. 2009). Half of the Pribilof foxes sampled had levels of $\Sigma$ PCBs, $\Sigma$ DDTs and $\Sigma$ CHLs higher than the mean liver levels of experimentally exposed foxes, while a few Pribilof foxes had levels of $\Sigma$ PCBs and $\Sigma$ CHLs an order of magnitude higher than experimentally exposed foxes. Liver concentrations of many if not most PCB and chlordane congeners are higher than blubber or fat concentrations on a lipid weight basis (Boon et al. 1994; Bachour et al. 1998; Helgason et al. 2013). This would suggest that Pribilof foxes are even more highly exposed than indicated by the concentrations obtained from fat samples in this study. Arctic foxes subjected to fasting, a seasonal occurrence, undergo a redistribution of contaminants in their tissues, resulting in concentration of some POPs and metabolism of others, increasing the potential for toxicity (Helgason et al. 2013). Some caution is warranted when comparing contaminant levels from different tissues, however, because fat and liver serve different physiological functions in the animal, contaminant effects thresholds may differ between tissues, and levels within and between tissues may vary seasonally. While the consequences of POP exposure on Arctic fox health are not yet fully understood, the adverse effects of POP exposure previously reported for this species, and the unprecedentedly high levels of POPs found in this study within the small, isolated and, therefore, particularly vulnerable Pribilof fox population is cause for concern. Arctic fox fossils, believed to date from the mid-Holocene, have been found on St. Paul (Guthrie 2004). Modern Pribilof foxes are morphologically (Pengilly 1981) and genetically distinct (Geffen et al. 2007), and are classified as an endemic subspecies (Angerbjorn et al. 2004). The fox population on St. Paul Island has declined dramatically over the past three decades because of decreasing natural food resources and direct persecution (White, unpubl. data). The high tissue levels of POPs found in Pribilof foxes represent potential health impacts, especially in light of other threats to 
the population, and should be further considered when addressing the conservation needs of this endemic subspecies.

\section{Acknowledgements}

The authors would like to thank: Terry Spraker for performing the fox necropsies; Karin Holser for salvaging dead foxes; Richard H. Boyer, Ronald L. Pearce, Daryle T. Boyd and Gladys K. Yanagida for analyses; Teri Rowles for funding of the analyses through the National Marine Fisheries Services' Marine Mammal Stranding and Health Response Program, and the communities of St. Paul and St. George islands and the Alaska Department of Fish and Game for permission to study and salvage foxes on the Pribilof Islands (ADFG Scientific Permits: 00-062; 01-050; 02-088; 03-077; 06-114). We would like to also thank the anonymous reviewers for their very helpful comments, which greatly improved the manuscript.

\section{Disclaimer}

Certain commercial equipment, instruments or software are identified in the paper in order to adequately specify the experimental procedure. Such identification does not imply recommendation or endorsement by NOAA Fisheries, nor does it imply the equipment is the best available for the purpose.

\section{Disclosure statement}

No potential conflict of interest was reported by the authors.

\section{Funding}

Funding for the analyses was provided by the Marine Mammal Health and Stranding Program of NOAA Fisheries.

\section{References}

AMAP 1998. Persistent organic pollutants. Oslo: Arctic Monitoring and Assessment Programme.

Andersen M.S., Fuglei E., Konig M., Lipasti I., Pedersen A. O., Polder A., Yoccoz N.G. \& Routti H. 2015. Levels and temporal trends of persistent organic pollutants (POPs) in Arctic foxes (Vulpes lagopus) from Svalbard in relation to dietary habits and food availability. Science of the Total Environment 511, 112-122.

Angerbjorn A., Hersteinsson P. \& Tannerfeldt M. 2004. Arctic fox Alopex lagopus. In C. Sillero-Zubiri et al. (eds.): Canids: foxes, wolves, jackals and dogs. Pp. 117123. Gland: International Union for the Conservation of Nature.

Bachour G., Failing K., Georgii S., Elmadfa I. \& Brunn H. 1998. Species and organ dependence of PCB contamination in fish, foxes, roe deer, and humans. Archives of Environmental Contamination and Toxicology 35, 666-673.

Ballschmiter K., Bacher R., Mennel A., Fischer R., Riehle U. \& Swerev M. 1992. The determination of chlorinated biphenyls, chlorinated dibenzodioxins, and chlorinated bibenzofurans by GC-MS. Journal of High Resolution Chromatography 15, 261-270.

Barrie L.A., Gregor D., Hargrave B., Lake R., Muir D., Shearer R., Tracey B. \& Bidleman T. 1992. Arctic contaminants: sources, occurrence and pathways. Science of the Total Environment 122, 1-74.

Beckmen K.B., Ylitalo G.M., Towell R.G., Krahn M.M., O’Hara T.M. \& Blake J.E. 1999. Factors affecting organochlorine contaminant concentrations in milk and blood of northern fur seal (Callorhinus ursinus) dams and pups from St. George Island, Alaska. Science of the Total Environment 231, 183-200.

Boon J.P., Oostingh I., van der Meer J. \& Hillebrand T.J. 1994. A model for the bioaccumulation of chlorobiphenyl congeners in marine mammals. European Journal of Pharmacology: Environmental Toxicology and Pharmacology Section 270, 237-251.

Bradley J.A., Secord D. \& Prins L. 1981. Age determination in the Arctic fox (Alopex lagopus). Canadian Journal of Zoology 59, 1976-1979.

Braune B. 2007. Temporal trends of organochlorines and mercury in seabird eggs from the Canadian Arctic, 1975-2003. Environmental Pollution 148, 599-613.

Burek K.A., Gulland F.M.D. \& O'Hara T.M. 2008. Effects of climate change on Arctic marine mammal health. Ecological Applications 18, S126-S134.

Cabana G. \& Rasmussen J.B. 1996. Comparison of aquatic food webs using nitrogen isotopes. Proceedings of the National Academy of Sciences of the United States of America 93, 10844-10847.

Clark R.G., Hobson K.A. \& Wassenaar L.I. 2006. Geographic variation in the isotopic $\left(\delta \mathrm{D}, \delta^{13} \mathrm{C}, \delta^{15} \mathrm{~N}, \delta^{34} \mathrm{~S}\right)$ composition of feathers and claws from lesser scaup and northern pintail: implications for studies of migratory connectivity. Canadian Journal of Zoology 84, 1395-1401.

Clausen J., Braestrup L. \& Berg O. 1974. The content of polychlorinated hydrocarbons in Arctic mammals. Bulletin of Environmental Contamamination and Toxicology 12, 529-534.

de Wit C.A., Fisk A.T., Hobbs K.E. \& Muir D.C.G. 2004. AMAP assessment 2002: persistent organic pollutants in the Arctic. Oslo: Arctic Monitoring and Assessment Programme.

Debier C., Pomeroy P.P., Dupont C., Joiris C., Comblin V., Le Boulengé E., Larondelle Y. \& Thomé J.-P. 2003. Quantitative dynamics of PCB transfer from mother to pup during lactation in UK grey seals Halichoerus grypus. Marine Ecology Progress Series 247, 237-248.

Dich J., Hoar Zahm S., Hanberg A. \& Adami H.-O. 1996. Pesticides and cancer. Cancer Causes and Control 1997, 420-443.

Dip R., Hegglin D., Deplazes P., Dafflon O., Koch H. \& Naegeli H. 2003. Age- and sex-dependent distribution of persistent oganochlorine pollutants in urban foxes. Environmental Health Perspectives 111, 16081612.

Ehrich D., Ims R.A., Yoccoz N.G., Lecomte N., Killengreen S.T., Fuglei E., Rodnikova A.Y., Ebbinge B.S., Menyushina I.E., Nolet B.A., Pokrovsky I.G., Popov I. Y., Schmidt N.M., Sokolov A.A., Sokolova N.A. \& Sokolov V.A. 2015. What can stable isotope analysis of top predator tissues contribute to monitoring of tundra ecosystems? Ecosystems 18, 404-416.

Ehrich D., Tarroux A., Stien J., Lecomte N., Killengreen S. T., Berteaux D. \& Yoccoz N.G. 2011. Stable isotope analysis: modelling lipid normalization for muscle and 
eggs from Arctic mammals and birds. Methods in Ecology and Evolution 2, 66-76.

Elliott J.E. 2005. Chlorinated hydrocarbon contaminants and stable isotope ratios in pelagic seabirds from the north Pacific ocean. Archives of Environmental Contaminantion and Toxicology 49, 89-96.

Evenset A., Carroll J., Christensen G.N., Kallenborn R., Gregor D. \& Gabrielsen G.W. 2007. Seabird guano is an efficient conveyer of persistent organic pollutants (POPs) to Arctic lake ecosystems. Environmental Science \& Technology 41, 1173-1179.

Fisk A.T., Hoekstra P.F., Gagnon J.-M., Duffe J., Norstrom R. J., Hobson K.A., Kwan M. \& Muir D. 2003. Influence of habitat, trophic ecology and lipids on, and spatial trends of, organochlorine contaminants in Arctic marine invertebrates. Marine Ecology Progress Series 262, 201-214.

Fuglei E., Bustnes J.O., Hop H., Mork T., Bjornfoth H. \& van Bavel B. 2007. Environmental contaminants in Arctic foxes (Alopex lagopus) in Svalbard: relationships with feeding ecology and body condition. Environmental Pollution 146, 128-138.

Geffen E., Waidyaratne S., Dalen L., Angerbjorn A., Vila C., Hersteinsson P., Fuglei E., White P.A., Goltsman M., Kapel C.M.O. \& Wayne R.K. 2007. Sea ice occurrence predicts genetic isolation in the Arctic fox. Molecular Ecology 16, 4241-4255.

Guthrie R.D. 2004. Radiocarbon evidence of mid-Holocene mammoths stranded on an Alaskan Bering Sea island. Nature 429, 746-749.

Helgason L.B., Wolkers H., Fuglei E., Ahlstrom O., Muir D. \& Jorgensen E.H. 2013. Seasonal emaciation causes tissue redistribution and an increased potential for toxicity of lipophilic pollutants in farmed Arctic fox (Vulpes lagopus). Environmental Toxicology and Chemistry 32, 1784-1792.

Hobson K.A. 1995. Reconstructing avian diets using stablecarbon and nitrogen isotope analysis of egg components: patterns of isotopic fractionation and turnover. The Condor 97, 752-762.

Hobson K.A., Alisauskas R.T. \& Clark R.G. 1993. Stablenitrogen isotope enrichment in avian tissues due to fasting and nutritional stress: implications for isotopic analysis of diet. The Condor 95, 388-394.

Hobson K.A., Piatt J.F. \& Pitocchelli J. 1994. Using stable isotopes to determine seabird trophic relationships. The Journal of Animal Ecology 63, 786-798.

Hoekstra P.F., Braune B.M., O'Hara T.M., Elkin B., Solomon K.R. \& Muir D.C.G. 2003. Organochlorine contaminant and stable isotope profiles in Arctic fox (Alopex lagopus) from the Alaskan and Canadian Arctic. Environmental Pollution 122, 423-433.

Hoekstra P.F., O’Hara T.M., Pallant S.J., Solomon K.R. \& Muir D.C.G. 2002. Bioaccumulation of organochlorine contaminants in bowhead whales (Balaena mysticetus) from Barrow, Alaska. Archives of Environmental Contaminantion and Toxicology 42, 497-507.

Iwata H., Tanabe S., Sakai N. \& Tatsukawa R. 1993. Distribution of persistent organochlorines in the oceanic air and surface seawater and the role of ocean on their global transport and fate. Environmental Science \& Technology 27, 1080-1098.

Kelly J.F. 2000. Stable isotopes of carbon and nitrogen in the study of avian and mammalian trophic ecology. Canadian Journal of Zoology 78, 1-27.

Klobes U., Vetter W., Glotz D., Luckas B., Skirnisson K. \& Hersteinsson P. 1998. Levels and enantiomeric rations of chlorinated hydrocarbons in livers of Arctic fox (Alopex lagopus) and adipose tissue and liver of a polar bear (Ursus maritimus) sampled in Iceland. International Journal of Analytical Chemistry 69, 67-81.

Krahn M.M., Becker P.R., Tilbury K.L. \& Stein J.E. 1997. Organochlorine contaminants in blubber of four seal species: integrating biomonitoring and specimen banking. Chemosphere 34, 2109-2121.

Krahn M.M., Hanson M.B., Baird R., Boyer R.H., Burrows D.G., Emmons C.K., Ford J.K.B., Jones L.L., Noren D.P., Ross P.S., Schorr G.S. \& Collier T.K. 2007. Persistent organic pollutants and stable isotopes in biopsy samples (2004/2006) from Southern Resident killer whales. Marine Pollution Bulletin 54, 1903-1911.

Krahn M.M., Herman D.P., Matkin C.O., Durban J.W., BarrettLennard L., Burrows D.G., Dahlheim M.E., Black N., LeDuc R.G. \& Wade P.R. 2006. Use of chemical tracers in assessing the diet and foraging regions of eastern North Pacific killer whales. Marine Environmental Research 63, 91-114.

Kucklick J.R., Struntz W.D.J., Becker P.R., York G.W., O'Hara T.M. \& Bohonowych J.E. 2002. Persistent organochlorine pollutants in ringed seals and polar bears collected from northern Alaska. Science of the Total Environment 287, 45-59.

Kurle C.M. \& Worthy G.A.J. 2001. Stable isotope assessment of temporal and geographic differences in feeding ecology of northern fur seals (Callorhinus ursinus) and their prey. Oecologia 126, 254-265.

Letcher R.J., Bustnes J.O., Dietz R., Jenssen B.M., Jorgensen E.H., Sonne C., Verreault J., Vijayan M.M. \& Gabrielsen G.W. 2010. Exposure and effects assessment of persistent organohalogen contaminants in Arctic wildlife and fish. Science of the Total Environment 408, 2995-3043.

Lie E., Larsen H.J.S., Larsen S., Johnsen G.M., Derocher A. E., Lunn N.J., Norstrom R.J., Wiig O. \& Skaare J.U. 2004. Does high organochlorine (OC) exposure impair the resistance to infection in polar bears (Ursus maritimus)? Part 1: effect of OCs on the humoral immunity. Journal of Toxicology and Environmental Health Part A: Current Issues 67, 555-582.

Loughlin T.R., Castellini M.A. \& Ylitalo G.Y. 2002. Spatial aspects of organochlorine contamination in northern fur seal tissues. Marine Pollution Bulletin 44, 1024-1034.

Lukyanova O.N., Tsygankov V.Y., Boyarova M.D. \& Khristoforova N.K. 2014. Pesticide biotransport by Pacific salmon in the northwestern Pacific Ocean. Doklady Biological Sciences 456, 188-190.

Martineau D., Lemberger K., Dallaire A., Labelle P., Lipscomb T.P., Michel P. \& Mikaelian I. 2002. Cancer in wildlife, a case study: beluga from the St. Lawrence estuary, Quebec, Canada. Environmental Health Perspectives 110, 285-292.

Muir D.C.G. \& Norstrom R.J. 2000. Geographical differences and time trends of persistent organic pollutants in the Arctic. Toxicology Letters 112, 93-101.

Nadelhoffer K., Shaver G., Fry B., Giblin A., Johnson L. \& McKane R. 1996. ${ }^{15} \mathrm{~N}$ natural abundances and $\mathrm{N}$ use by tundra plants. Oecologica 107, 386-394.

Newsome S.D., Park J.-S., Henry B.W., Holden A., Fogel M.L., Linthicum J., Chu V. \& Hooper K. 2010. Polybrominated diphenyl ether (PBDE) levels in peregrine falcon (Falco peregrinus) eggs from California correlate with diet and human population density. Environmental Science \& Technology 44, 5248-5255.

Norheim G. 1978. The composition and distribution of PCB in Arctic fox (Alopex lagopus) caught near Longyearbyen on Svalbard. Acta Pharmacologica et Toxicologica 42, 7-13. 
Norstrom R.J., Belikov S.E., Born E.W., Garner G.W., Malone B., Olpinski S., Ramsay M.A., Schliebe S., Stirling I., Stishov M.S., Taylor M.K. \& Wiig O. 1998. Chlorinated hydrocarbon contaminants in polar bears from eastern Russia, North America, Greenland, and Svalbard: biomonitoring of Arctic pollution. Archives of Environmental Contamination and Toxicology 35, 354-367.

Norstrom R.J. \& Muir D.C.G. 1994. Chlorinated-hydrocarbon contaminants in Arctic marine mammals. Science of the Total Environment 154, 107-128.

Pedersen K.E., Styrishave B., Sonne C., Dietz R. \& Jenssen B.M. 2015. Accumulation and potential health effects of organohalogenated compounds in the Arctic fox (Vulpes lagopus) - a review. Science of the Total Environment 502, 510-516.

Pengilly D. 1981. Variation in skull measurements of North American Arctic foxes, Alopex lagopus and the taxonomic status of A. l. hallensis and A.l. pribilofensis. M.S. thesis, University of Alaska, Fairbanks

Post D.M., Layman C.A., Arrington D.A., Takimoto G., Quattrochi J. \& Montana C.G. 2007. Getting to the fat of the matter: models, methods and assumptions for dealing with lipids in stable isotope analyses. Oecologia 152, 179-189.

R Development Core Team. 2015. R: a language and environment for statistical computing. Vienna: R Foundation for Statistical Computing.

Randhawa N., Gulland F.M.D., Ylitalo G.M., DeLong R. \& Mazet J.A.K. 2015. Sentinel California sea lions provide insight into legacy organochlorine exposure trends and their association with cancer and infectious disease. One Health 1, 37-43.

Ricca M.A., Keith Miles A. \& Anthony R.G. 2008. Sources of organochlorine contaminants and mercury in seabirds from the Aleutian archipelago of Alaska: inferences from spatial and trophic variation. Science of the Total Environment 406, 308-323.

Robson B.W., Goebel M.E., Baker J.D., Ream R.R., Loughlin T.R., Francis R.C., Antonelis G.A. \& Costa D. P. 2004. Separation of foraging habitat among breeding sites of a colonial marine predator, the northern fur seal (Callorhinus ursinus). Canadian Journal of Zoology 82, 20-29.

Roth J.D. \& Hobson K.A. 2000. Stable carbon and nitrogen isotopic fractionation between diet and tissue of captive red fox: implications for dietary reconstruction. Canadian Journal of Zoology 78, 848-852.

Schell D.M., Barnett B.A. \& Vinette K.A. 1998. Carbon and nitrogen isotope ratios in zooplankton of the Bering, Chukchi and Beaufort seas. Marine Ecology Progress Series 162, 11-23.

Skaare J.U. 1996. Environmental pollutants in marine mammals from the Norwegian coast and Arctic. The Science of the Total Environment 186, 25-27.

Sloan C.A., Brown D.W., Pearce R.W., Boyer R.H., Bolton J.L., Burrows D.G., Herman D.P. \& Krahn M.M. 2005. Determining aromatic hydrocarbons and chlorinated hydrocarbons in sediments and tissues using accelerated solvent extraction and gas chromatography/mass spectrometry. In G.K. Ostrander (ed.): Techniques in aquatic toxicology. Vol. 2. Pp. 631-651. Boca Raton, FL: CRC Press.

Sloan C.A., Brown D.W., Ylitalo G.M., Buzitis J., Herman D.P., Burrows D.G., Yanagida G.K., Pearce R.W., Bolton J.L., Boyer R.H. \& Krahn M.M. 2006. Quality assurance plan for analyses of environmental samples. Technical Memorandum NMFS-NWFSC-77. Seattle, WA: Northwest Fisheries Science Center.

Sonne C., Wolkers H., Leifsson P.S., Iburg T., Jenssen B.M., Fuglei E., Ahlstrom O., Dietz R., Kirkegaard M., Muir D. C.G. \& Jorgensen E.H. 2009. Chronic dietary exposure to environmental organochlorine contaminants induces thyroid gland lesions in Arctic foxes (Vulpes lagopus). Environmental Research 109, 702-711.

Sonne C., Wolkers H., Leifsson P.S., Jenssen B.M., Fuglei E., Ahlstrom O., Dietz R., Kirkegaard M., Muir D.C.G. \& Jorgensen E. 2008. Organochlorine-induced histopathology in kidney and liver tissue from Arctic fox (Vulpes lagopus). Chemosphere 71, 1214-1224.

Sonne C., Wolkers H., Riget F.F., Jensen J.E.B., Teilmann J., Jenssen B.M., Fuglei E., Ahlstrom O., Dietz R., Muir D. C.G. \& Jorgensen E.H. 2009. Mineral density and biomechanical properties of bone tissue from male Arctic foxes (Vulpes lagopus) exposed to organochlorine contaminants and emaciation. Comparative Biochemistry and Physiology C-Toxicology \& Pharmacology 149, 97103.

Tieszen L.L., Boutton T.W., Tesdahl K.G. \& Slade N.A. 1983. Fractionation and turnover of stable carbon isotopes in animal tissues: implications for $\delta^{13} \mathrm{C}$ analysis of diet. Oecologia 57, 32-37.

Tuerk K.J.S., Kucklick J.R., McFee W.E., Pugh R.S. \& Becker P.R. 2005. Factors influencing persistent organic pollutant concentrations in the Atlantic white-sided dolphin (Lagenorhynchus acutus). Environmental Toxicology and Chemistry 24, 1079-1087.

Vander Pol S.S., Becker P.R., Kucklick J.R., Pugh R.S., Rosenau D.G. \& Simac K.S. 2004. Persistent organic pollutants in Alaskan murre (Uria spp.) eggs: geographical, species, and temporal comparisons. Environmental Science \& Technology 38, 1305-1312.

Verreault J., Norstrom R.J., Ramsay M.A., Mulvihill M. \& Letcher R.J. 2006. Composition of chlorinated hydrocarbon contaminants among major adipose tissue depots of polar bears (Ursus maritimus) from the Canadian High Arctic. Science of the Total Environment 370, 580-587.

Wainright S.C., Haney J.C., Kerr C., Golovkin A.N. \& Flint M.V. 1998. Utilization of nitrogen derived from seabird guano by terrestrial and marine plants at St. Paul, Pribilof Islands, Bering Sea, Alaska. Marine Biology 131, 63-71.

Wang-Andersen G., Skaare J.U., Prestrud P. \& Steinnes E. 1993. Levels and congener pattern of PCBs in Arctic fox, Alopex lagopus, in Svalbard. Environmental Chemistry 82, 269-275.

White P.A. 1992. Social organization and activity patterns of the Arctic fox (Alopex lagopus pribilofensis) on St. Paul Island, Alaska. M.S. thesis, University of California, Berkeley.

White P.A. 2001. Artificial food sources alter distribution and negatively impact the health of an insular canid. Paper presented at the Meeting of the Society for Conservation Biology, 29 July-1 August, Hilo, HI.

White P.A. 2010. Arctic foxes (Alopex lagopus) and human settlements. In S.D. Gehrt et al. (eds.): Urban carnivores: ecology conflict, and conservation. Pp. 76-77. Baltimore, MD: John Hopkins University Press.

Ylitalo G.M., Baird R.W., Yanagida G.K., Webster D.L., Chivers S.J., Bolton J.L., Schorr G.S. \& McSweeney D.J. 2009. High levels of persistent organic pollutants measured in blubber of island-associated false killer whales 
(Psuedorca crassidens) around the main Hawaiian Islands. Marine Pollution Bulletin 58, 1922-1952.

Ylitalo G.M., Matkin C.O., Buzitis J., Krahn M.M., Jones L. L., Rowles T. \& Stein J.E. 2001. Infuence of life-history parameters on organochlorine concentrations in freeranging killer whales (Orcinus orca) from Prince William Sound, AK. Science of the Total Environment 281, 183-203.
Ylitalo G.M., Yanagida G.K., Hufnagle L. Jr. \& Krahn M.M. 2005. Determination of lipid classes and lipid content in tissues of aquatic organisms using a thin layer chromatography/flame ionization detection (TLC/FID) microlipid method. In G.K. Ostrander (ed.): Techniques in aquatic toxicology. Vol. 2. Pp. 227-237. Boca Raton, FL: CRC Press. Zar J.H. 1984. Biostatistical analysis. 2nd edn. Englewood Cliffs, NJ. Prentice-Hall. 